\title{
sciendo
}

\section{The influence of the implementation of ERP systems on the performance of an organization}

\author{
Laura-Eugenia-Lavinia BARNA \\ Bucharest University of Economic Studies, Bucharest, Romania \\ barnalaura15@stud.ase.ro \\ Roxana Dana IGNA \\ Bucharest University of Economic Studies, Bucharest, Romania \\ roxana.igna95@yahoo.ro
}

\begin{abstract}
In this paper, I examined how the adoption and implementation of Enterprise Resource Planning systems influences an organization's performance. Performance is a key component that underlies the organization's activity. Enterprise Resource Planning systems are used to manage the activities of an organization (accounting, procurement, compliance, production, project management and other distribution chain operations). The impact of implementing Enterprise Resource Planning systems may differ from organization to organization. The main purpose of the paper is to present the most important performance indicators that are influenced by the implementation of Enterprise Resource Planning systems, but also what is their impact on the entire activity of an organization. The research method used is a quantitative research based on the questionnaire where we identified how Enterprise Resource Planning systems influence the performance of the organization. The data collected were useful to answer the main research questions formulated in the paper. The results obtained based on the questionnaire showed that organizations that implemented Enterprise Resource Planning systems obtained more favorable values of performance indicators than organizations that did not implement them. These Enterprise Resource Planning systems also have a role in the sustainable development of the organization, but in principle Enterprise Resource Planning systems are useful to improve the performance of the organization.
\end{abstract}

Keywords: ERP systems, performance, activity, implementation, sustainability.

\section{Introduction}

Over time, the economic environment and the IT sector have developed, so that organizations have needed increasingly high-performance equipment and systems that meet the requirements of the market and managers to operate in the best possible conditions. Information technology is constantly evolving. Hence the need to automate as many business processes within an organization. Hung (2009) states that many organizations have changed their strategy so that they can "adopt application software packages" and cope with changes and evolutions in the business environment.

Many organizations have analyzed various studies in order to make the optimal decision on investing in Enterprise Resource Planning (ERP) systems as efficient as possible in order to improve the results obtained, but also to improve the performance of the organization. According to Oracle (2020), ERP systems have the role of uniting a series of business processes, so that the data is as accurate and complete as possible. All data processed using ERP systems are stored in a database, thus avoiding data duplication and providing data integrity.

In this article, I will analyze both the relationship between ERP systems and the performance of the organization, as well as the main indicators that change due to the implementation of ERP systems. According to Trott and Hoecht (2004, quoted by Hassab Elnaby

DOI: $10.2478 /$ picbe-2021-0026

(C) 2021 L.-E.-L. Barna, R. D. Igna, published by Sciendo.

This work is licensed under the Creative Commons Attribution 4.0 License. 
et al., 2012), ERP systems "offer many benefits to the organization" so that organizations can meet their expectations of providing managers and stakeholders with accurate, complete and in real time information / data, so that managers can make the best decisions. Muhindo et al. (2014) state that the business environment contains transactions that "generate information for good performance analysis".

The ERP system can be considered a software tool has a role in integrating all the information within an organization in a single platform. This ensures data transparency and facilitates access to information. Any ERP system must ensure efficiency, effectiveness and adaptability. According to Aladwani (2001), an ERP system can help different parts of the organization share data and knowledge, reduce costs, and improve management of business processes.

Improving the performance of an organization includes business re-engineering activities, processes for continuously improving the business and the quality of services or products offered. To see if an organization is efficient, the main performance indicators must be analyzed. Managers are interested in the overall performance of an organization, while investors (current and potential) perceive performance through return on investment (Gruian, 2010, pp. 243).

The word performance comes from Latin, but the meaning comes from English which "consists in completing a proposed activity" or through which an organization "achieves its proposed objectives" (Chirilă, 2004).

Performance can also be defined from the perspective of the cost-value relationship (decreasing the cost and increasing the external and internal value).

Chirilă (2004) defined the two concepts of external and internal value as follows: "the external value of an organization means that the market value is higher than the book value of the assets it holds, and the internal value means that the organization creates economic added value , so a positive net value after remuneration of all factors of production, including the cost of equity." According to Bit software (2016), a company's performance indicators can be classified as follows:

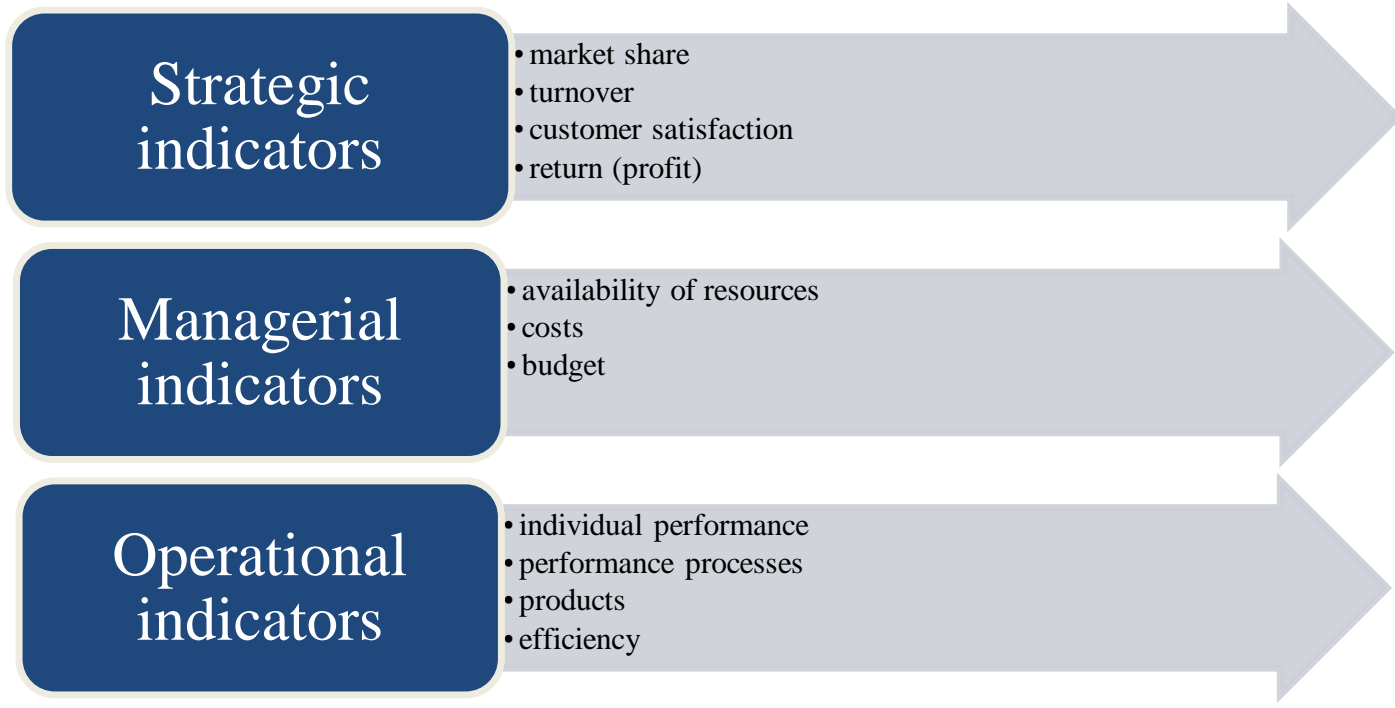

Figure 1. Company's performance indicators

Source: Bit software, 2016.

As shown in Figure 1, a company's performance indicators can be classified as follows: strategic indicators, managerial indicators and operational indicators. 
An organization can be considered performance only if it is at the same time productive, efficient and effective. This can only be done if efficient computer systems are used (example: ERP systems).

The article is structured as follows: a literature review section where the main analyzed articles are presented, a section on the research methodology where the chosen research method is presented, a section to analyze the results obtained based on the questionnaire and a section that it includes the conclusions formulated based on the analyzed results.

\section{Literature review}

The ERP system (acronym for Enterprise Resource Planning system) is a computer program with the role of managing the activity, processes and resources of an organization. Through this ERP system, a manager can control the business and make decisions much easier thanks to the correct and complete information provided in real time by ERP systems.

Hung (2009) found that a configured system fits the requirements and tasks of the organization, when "performance should improve", otherwise performance would become reduced in case of incompatibility.

Studies conduct by Weil and Olson (1989, in Hung, 2009) found that $70 \%$ of configured systems improved the performance of the organization. Sol et al. (2000, in Hung, 2009) examined the fit of ERP with the organization through data and processes.

Stanciu and Tinca (2013, p. 630) found that successful implementation of ERP systems depends on the following criteria: "management commitment, project opposition, corporate culture, change planning and management, user training and launch strategy". "The commitment of management is essential because it provides future objectives and directions" (Stanciu and Tinca, 2013, p. 630), ensures the necessary resources, but also the monitoring of the project development. IT specialists have found that these criteria are important "in business and decisionmaking processes" (Chou and Chang, 2008 in Stanciu and Tinca, 2013).

Dumitru et al. (2013), considers that the literature on the implementation of ERP systems is quite underdeveloped and they noticed that "many new organizations proposing IT solutions were founded after 2000, as a result of the economic development". It was thus found in the study conducted by Dumitru et al. (2013, p. 512) that good business decides to implement ERP systems because it considers that "the need for rigorous control and coherence" can be ensured only with the help of these systems. Many organizations want to replace old systems with new, highperformance and efficient ones.

To understand how modules work and the entire ERP system, one must first understand the flow of information (Scott, 2003 in Madapusi and D'Souza, 2012, p. 25). Madapusi and D'Souza (2012) consider that ERP systems reduce the need for information processing, by creating automated tasks.

Velcu (2007) presents in her article the reasons why an ERP system should be implemented within an organization. Yet and Nicolaou (2004, in Velcu, 2007) argue that the implementation of ERP systems "positively influences the ability of organizations to obtain greater financial benefits compared to organizations that have not implemented such systems."

Regarding the successful implementation of ERP systems, the following aspects were identified by Velcu (2007):

a) project phase - the level of cost and time for the completion and commissioning of ERP systems;

b) shakedown phase - the post-implementation adjustment period takes place (it is observed if the system is efficient and if it corresponds to the managers' requirements); 
c) phase before and after implementation - it is observed if the expected benefits / objectives are met (economic benefits, improvement of business practices, improvement of decisions).

Shang and Seddon (2002, in Velcu, 2007) noted that the main benefits of ERP systems are better planning and management of resources, but also better monitoring of the financial performance of the organization. Thus, in order to have a clear vision on the performance of the organization, Velcu (2007) recommends managers and users of financial - accounting information to consider customer satisfaction with services or products provided, efficiency of internal processes, but also the ability of organizations to grow future.

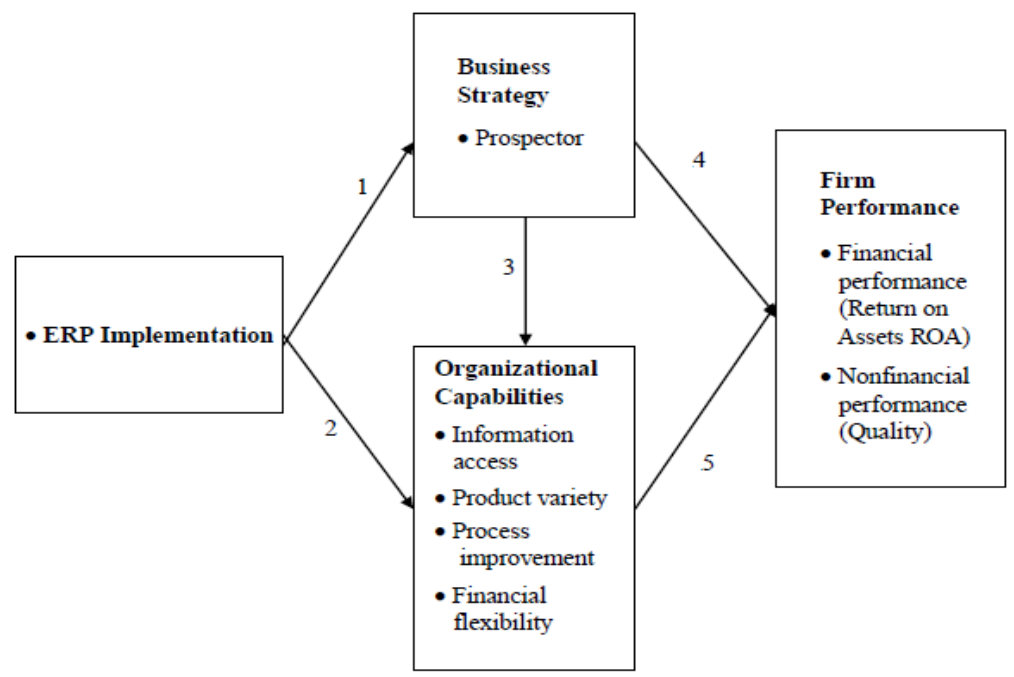

Figure 2. Impact of ERP implementation on organization performance

Source: Hassab Elnaby et al., 2012.

Hassab Elnaby et al. (2012) states that the successful implementation of ERP systems consists in the organization's ability to adapt to new changes. This can only be achieved if the organization provides training programs and work procedures for employees so that they can adapt to the new changes brought about by the implementation of these ERP systems. It was found by Langfield-Smith (1997, in Hassan Elnaby et al., 2012, p. 621) that the process of implementing ERP systems affects the business strategy. The organization's strategy must also be reconfigured due to the implementation of these systems. First, a "long-term planning must be made that includes mergers and acquisitions, product supply, supplier and customer relationship management, and product innovation" (Porter and Millar, 1985, in Hassan Elnaby et al., 2012, p. 621).

Shang and Seddon (2002, in Hassab Elnaby et al., 2012) consider that ERP systems have an important role to play in achieving "strategic, organizational, management, operational and IT infrastructure objectives". They found that ERP systems allow precise and real-time coordination of information. Horvath (2001, in Hassab Elnaby et al., 2012) believes that ERP systems have the role of "reducing inventory and administration costs and increasing the capacity to respond to market demands."

Nicolaou and Bhattacharya (2006) consider that ERP systems ensure the increase of labor productivity and, implicitly, the increase of the company's performance. 
The role of ERP systems is to provide information immediately and in real time, this favoring obtaining "competitive and strategic advantages" (Hassab Elnaby et al., 2012).

According to the website Cft.ro (2018), an ERP system provides the following advantages: the information is stored in a common database that is easy to access, improving business processes, increasing the quality of services offered, managers make decisions much easier based on the information

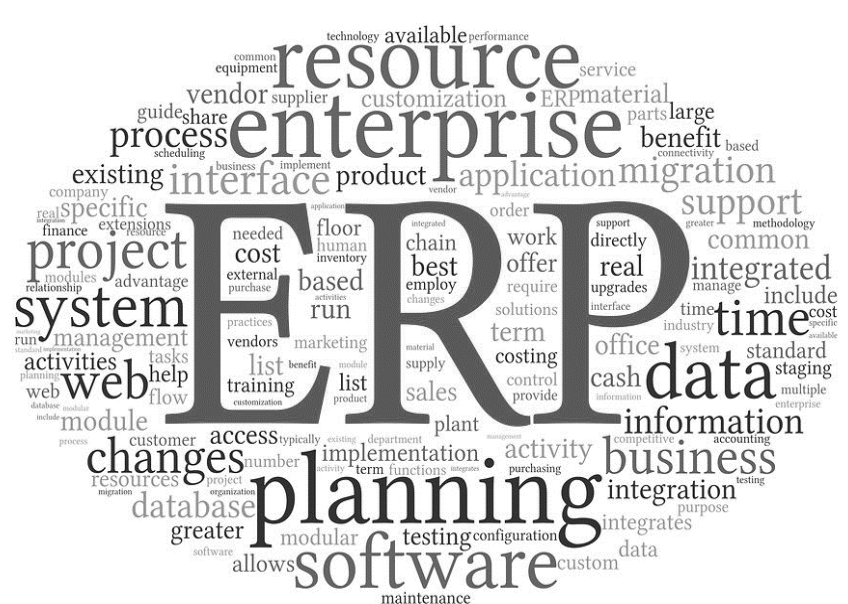

Figure 3. Enterprise Resource Planning system provided by the ERP systems.

The main disadvantages of implementing ERP systems are: higher implementation costs, difficult and long-lasting implementation, allocating a greater number of human resources and time in the process of implementing ERP systems.

Oracle (2020) presents the main benefits of ERP systems to an organization:

- business data is accurate and complete generated in real time;

- low operating costs;

- improved data sharing to users of financial-accounting information;

- tasks automation;

- design easy to use by users of financial - accounting information;

- reduced risks due to the implemented financial controls;

- low costs for certain operations.

Tobon et al. (2018) believes that any organization seeks to have the highest possible productivity, access to information and the highest possible managerial performance. Tobon et al. (2018) also presented the main principles of ERP systems: "hierarchy, incorporation of business processes and centralized data management".

ERP systems ensure the sustainability of the organization, because most activities become automated, and the amount of printed or photocopied documents is reduced by about $40 \%$.

Hassan Elnaby et al. (2012) says that the implementation of ERP systems has a positive impact on the adoption of a business strategy as efficient as possible, but also to improve the organization's performance.

Wieder (2007) found in recent studies conducted by SAP (2003a, b), Oracle (2003a, b) and PeopleSoft (2003) that ERP systems play an important role in financial performance. Following research by Poston and Grabski (2001), they found an increase in efficiency in terms of "reducing the number of employees, but also the ratio of employees to revenue for each year after the implementation of ERP."

To see if an organization's performance situation has improved or worsened, Hunton et al. (2003) compared 3 important indicators such as: "return on assets, return on investment and turnover for organizations that have adopted ERP and those that have not." Thus, he noticed that 
the performance and efficiency of the organization improved after the implementation of ERP systems.

In the next section, I will detail the research method used to verify whether ERP systems ensure the improvement of an organization's performance.

\section{Methodology}

PICBE |

In this section I will present the research method used to investigate the influence of the implementation of ERP systems on the performance of an organization, but also the way in which its sustainability is ensured. In the research we considered the topic both the impact of ERP systems on the performance of an organization, and how to ensure the sustainability of an organization with the help of ERP systems.

To research this, I used a quantitative research method, the questionnaire. In addition to the questionnaire, I took into account the results obtained by other authors who analyzed the performance in different aspects as follows in the next table:

Table 1. The main indicators analyzed by other authors to observe how ERP systems influence the performance of an organization

\begin{tabular}{|l|r|}
\hline $\begin{array}{c}\text { Author and year of publication of } \\
\text { the article }\end{array}$ & \multicolumn{1}{c|}{ Main indicators analyzed in their study } \\
\hline Nicolaou (2008) & - $\begin{array}{l}\text { financial performance (profitability, sales volume, revenue } \\
\text { growth) } \\
\text { strategic performance (strategic competitiveness, strength of } \\
\text { strategic position, market share) }\end{array}$ \\
\hline Nicolaou and Bojor (2004) & - $\quad \begin{array}{l}\text { different types of performance measurement (accounting, } \\
\text { market and risk measures) } \\
\text { financial indicators (return on assets, return on sales, cost of } \\
\text { goods sold in relation to sales, employees in relation to sales, } \\
\text { turnover in stock) }\end{array}$ \\
\hline HassabElnaby et al. (2012) & $\begin{array}{l}\text { financial performance (return on assets) } \\
\text { non-financial performance (quality) }\end{array}$ \\
\hline
\end{tabular}

Source: Authors' own creation made based on the information extracted from the article of Dumitru et al., 2013.

Dumitru et al. (2013) observed several significant aspects in terms of the impact of ERP systems on an organization's performance: strategic aspects (competitiveness, market share), operational (order and inventory management efficiency), customer-related aspects (satisfaction and quality the relationship between the organization and the client), aspects related to management (business knowledge, responsibility), financial aspects (sales, costs, revenues, expenses).

Umble et al. (2003) found that "65\% of executives believe that ERP systems would affect their business in the beginning", because they believe that problems may occur in the implementation process or employees may not understand how the entire activity of an ERP system works.

The questionnaire realized includes 22 questions, both general questions and questions specific to the research topic. The questionnaire was published on the isondaje.ro platform between November 13 and November 24, 2020 and 112 people answered the questionnaire $(82,14 \%$ women and $17.86 \%$ men), residing in urban areas $(78,6 \%)$ and in rural areas $(21,4 \%)$. 
Table 2. Gender and area of residence of the respondents

\begin{tabular}{|c|c|c|c|c|}
\hline Gender & Urban areas & Rural areas & Total / gender \\
\hline Women & 77 & & 15 & 92 \\
\hline Men residence & 11 & & 9 & 20 \\
\hline $\begin{array}{c}\text { Total / area of } \\
\text { residence }\end{array}$ & $\mathbf{8 8}$ & $\mathbf{2 4}$ & $\begin{array}{c}\text { Total respondents: } \\
\mathbf{1 1 2}\end{array}$ \\
\hline
\end{tabular}

Most respondents work in the economic field (76,8\%), followed by those working in the IT field (8\%), banks $(3,6 \%)$, education $(2,7 \%)$, sales $(1,8 \%)$, logistics and marketing $(1,8 \%)$ and others $(5,4 \%)$. To the answer "others", the respondents answered that they work in finance, insurance, audit, etc. Most of the companies in which the respondents work have entrepreneurial initiatives as can be seen in table 3:

Table 3. Entrepreneurial initiatives of the company

\begin{tabular}{|c|c|c|}
\hline Gender $\quad$ Initiatives & Yes & No \\
\hline Women & 65 & 27 \\
\hline Men & 11 & 9 \\
\hline Total & 76 & 36 \\
\hline
\end{tabular}

Source: own creation created based on the results obtained.

It can be seen from table 3 , that $67.86 \%$ of companies have entrepreneurial initiatives, the rest not having such initiatives.

The main questions formulated that will be analyzed in the next section are:

$\mathrm{Q}_{1}$ : Most respondents said that ERP systems increase labor productivity?

$\mathrm{Q}_{2}$ : ERP systems have a great impact on business infrastructure?

These questions will be analyzed in the next section.

\section{Results and discussion}

In this section I will present and analyze the main results obtained based on the questionnaire.

When asked "What ERP systems have you used or are you currently using?", respondents stated the following:

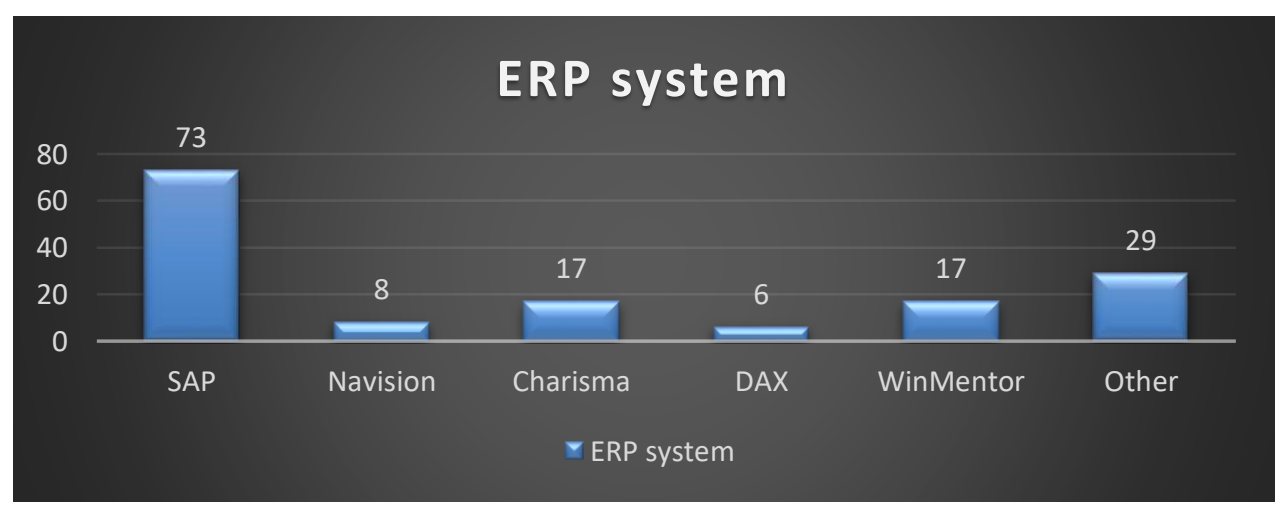

Figure 4. ERP system used by respondents

Source: Authors' own research.

DOI: 10.2478/picbe-2021-0026, pp. 268-279, ISSN 2558-9652 |

Proceedings of the $15^{\text {th }}$ International Conference on Business Excellence 2021 
As can be seen in Figure 4, the most used ERP system is SAP (73 respondents meaning 48.7\%), followed by Charisma (17 respondents meaning $11.3 \%$ ) and WinMentor (17 respondents meaning 11.3\%). To the "Other" answer, the respondents stated that they also use SAGA, Ciel, BORG, Oracle, Expert-Contab. Approximately $48.2 \%$ of respondents who use ERP systems have an experience of using these systems of less than 6 months and $23.2 \%$ have either an experience of between 6 months and one year, or an experience of between 1 and 5 years. The rest of the respondents have more than 5 years of experience.

Next I will analyze the $\mathrm{Q}_{1}$ question which referred to the fact that the most respondents said that ERP systems increase labor productivity. Analyzing the responses received from respondents, I found that most respondents stated that ERP systems improve the performance of an organization $(60.7 \%)$, to the detriment of increasing labor productivity $(27.7 \%)$. It follows that the $\mathrm{Q}_{1}$ question is infirmed. The other respondents stated that ERP systems have the role of reducing costs or improving the image of the organization.

Table 4. The influence of using ERP systems within an organization

\begin{tabular}{|l|r|}
\hline \multicolumn{2}{|c|}{ The influence of using ERP systems within an organization: } \\
\hline Improve performance & 68 \\
\hline Reduce costs & 6 \\
\hline Increase labor productivity & 31 \\
\hline Improve the company's image & 4 \\
\hline Other & 3 \\
\hline \multicolumn{1}{|c|}{ Total } & $\mathbf{1 1 2}$ \\
\hline
\end{tabular}

Source: Authors' own research.

Also, based on the questionnaire, I also found that the tasks are in principle $75 \%$ automated. Respondents also stated that an organization should invest in modern technologies to ensure environmental protection and resource conservation of $96.4 \%$.

The role of ERP systems is to ensure that information is much clearer and easier to understand for both managers and users of financial accounting information, and then to reduce the amount of printed documents and reduce electricity consumption. Madapusi and D'Souza (2012) found that ERP systems are used by the organization in order to "reduce uncertainty and improve operational performance."

Given the $\mathrm{Q}_{2}$ question, that "ERP systems have a great impact on business infrastructure", I can say that most respondents stated that ERP systems have an impact on business infrastructure in percent of $56.3 \%$.

In Figure 5, I presented the main modules of the ERP system that should be implemented in order to improve the operational performance of an organization (information availability, information quality, standardization, inventory management and on-time delivery). 


\section{ERP System Implementation Status}

\section{-ERP system modules}

-Example: Financials, Controlling, Plant Maintenance, Materials Management, Production Planning, Project System, Sales \& Distribution, General Logistics, Quality Management, Human Resources, SCM, CRM, E-commerce, APO/APS

\section{Operational} Performance
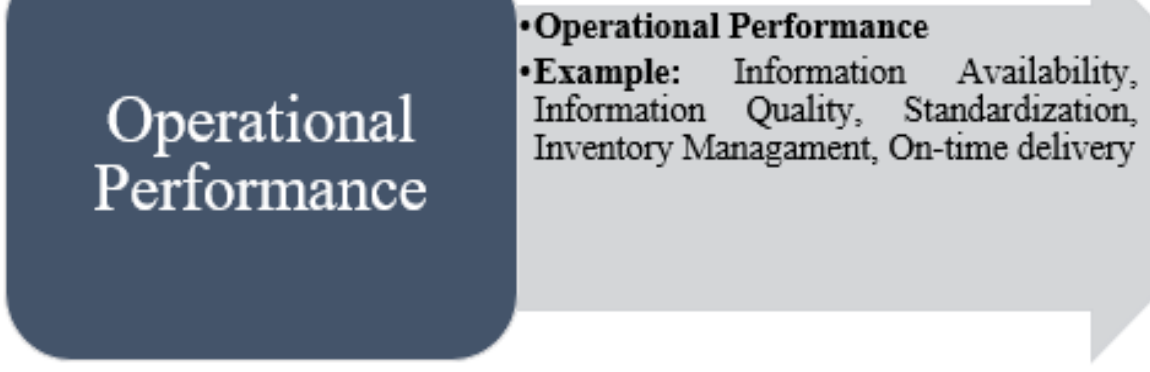

\section{Figure 5. The main modules of the ERP system that should be implemented in order to improve the operational performance of an organization}

Source: Madapusi and D’Souza, 2012.

If the organization installs the modules presented in table 5, then they will be able to establish a combination of strategies so as to obtain operational benefits.

Table 5. Relationship between ERP system modules and the performance of the company

\begin{tabular}{|c|c|c|}
\hline \multirow{11}{*}{$\begin{array}{l}\text { ERP system } \\
\text { modules }\end{array}$} & Financials: & $\begin{array}{l}\text { Contain "operational aspects of the general accounting and } \\
\text { financial information for a business unit." }\end{array}$ \\
\hline & Controlling: & $\begin{array}{l}\text { It's a "business unit's cost structures and the factors that influence } \\
\text { them." }\end{array}$ \\
\hline & Materials management: & This module comprises all activities. \\
\hline & Production planning: & $\begin{array}{l}\text { It's used for "different phases, tasks, and methodologies used in } \\
\text { the planning of production and the process of production itself." }\end{array}$ \\
\hline & Sales and distribution: & $\begin{array}{l}\text { This module "enables the management of all sales and distribution } \\
\text { activities." }\end{array}$ \\
\hline & General logistics: & $\begin{array}{l}\text { This module "contains the tools and reports necessary to analyze } \\
\text { and manage the status in supply-chain forecasts." }\end{array}$ \\
\hline & Project system: & $\begin{array}{l}\text { Contain "all aspects of activities, resource planning, and } \\
\text { budgeting of complex tasks." }\end{array}$ \\
\hline & Plant maintenance: & $\begin{array}{l}\text { Maintenance "of plant systems and supports graphical } \\
\text { representations, connection to geographic information systems, } \\
\text { and detailed diagrams." }\end{array}$ \\
\hline & Quality management: & $\begin{array}{l}\text { Ensure "quality planning, inspection and control, and compliance } \\
\text { with international quality standards to ensure that a business unit } \\
\text { employs a unified approach to total quality management for all its } \\
\text { business areas." }\end{array}$ \\
\hline & Human resources: & $\begin{array}{l}\text { This module includes "all business processes required to } \\
\text { efficiently manage a business unit's human resources needs." }\end{array}$ \\
\hline & Supply chain management: & $\begin{array}{l}\text { Include "planning and execution capabilities to manage inter- } \\
\text { business unit supply chains operations." }\end{array}$ \\
\hline
\end{tabular}




\begin{tabular}{|l|l|l|}
\hline & $\begin{array}{l}\text { Customer relationship } \\
\text { management: }\end{array}$ & $\begin{array}{l}\text { Include “automating functions such as sales, marketing, customer } \\
\text { service, and collaborative order management." }\end{array}$ \\
\cline { 2 - 3 } & E-commerce: & Facilitates “access to ERP processes and data from anywhere." \\
\hline $\begin{array}{l}\text { Advance planner } \\
\text { optimizer/advance planner } \\
\text { scheduler: }\end{array}$ & Ensures complex processes. \\
\hline \multirow{5}{*}{ Performance } & Information availability: & Real-time information from the ERP system. \\
\cline { 2 - 3 } & Information quality: & Consistent and reliable information from the ERP system. \\
\cline { 2 - 3 } & Standardization: & Streamlining and rationalization of business processes. \\
\cline { 2 - 3 } & Inventory management: & Refers to changes in the inventory management processes. \\
\cline { 2 - 3 } & $\begin{array}{l}\text { Refers to changes in the order management/order cycle that } \\
\text { facilitate on-time delivery of products/services to } \\
\text { customers. }\end{array}$ \\
\hline
\end{tabular}

PICBE | 277

Regarding the trainings for the involvement of employees on the sustainability side (sustainable development) of the organization and the use of ERP systems, $97.3 \%$ of the respondents stated that if an organization wants to improve its performance it must ensure regular training programs. This has also been confirmed by Chand et al. (2005, quoted by Velcu, 2007) who found that the main benefits of the ERP system are "to reduce costs, increase revenue and improve the market value" of the organization. It was found that some organizations can improve or not their performance by implementing ERP systems, only if they have a very good strategy and well-defined work procedure within the organization.

Lečić and Kupusinac (2013) noted that ERP systems used over a longer period of time ensure an increase in an organization's overall performance, and business processes remain the same.

\section{Conclusions}

Data collection using the questionnaire was quite difficult to observe how ERP systems play a role in improving the organization's performance. The research was performed both on the basis of the results of the questionnaire and on the basis of the studied articles.

As stated by Dumitru et al. (2013), if one uses "several criteria for evaluating performance" of an organization, then one can understand the situation of that organization in a more complex way. In order for an organization to survive in an ever-evolving economic environment, a company must have a clear business model and invest in an efficient IT system so that it can operate in optimal conditions. . Thus, ERP systems are "top software packages" (Stanciu and Tinca, 2013) for which the organization should invest in them to achieve the desired results.

In the paper I also presented the main modules that should be implemented so that an organization can meet its objectives and achieve the desired performance, but also certain benefits. Following the study, it was found that ERP systems have a role in improving the performance of the organization, as well as the market value. Thus, with the help of ERP systems, managers have much easier control over the organization, the information is much clearer and decisions can be made much easier.

In conclusion, for the implementation of ERP systems to be successful, an organization must have very well defined objectives and the strategy it will use after the implementation of ERP systems. 
At the same time, organizations must have working procedures on how to use ERP systems and provide employees with training programs to make easily with the transition to using ERP systems.

\section{References}

Aladwani, A. M. (2001). Change management strategies for successful ERP implementation, Business Process Management Journal, 7(3), 266-275.

Bit software (2016). 5 indicatori de performanță importanţi pentru industria de distribuție. Retrieved from: https://info.bitsoftware.eu/blog/bitsoftware-ro/5-indicatori-de-performan ta-importanti-pentru-industria-de-distributie.

Cft.ro (2018). ERP systems. Retrieved from: http://www.cft.ro/wp-content/uploads/2018/02/Ceinseamna-ERP.pdf.

Chirilă, E. (2004). Definirea și măsurarea performanței întreprinderilor. Retrieved from: http://steconomiceuoradea.ro/anale/volume/2004/28.pdf.

Dumitru, V. F; Albu, N.; Albu, C. N; Dumitru, M. (2013). ERP implementation and organizational performance. A Romanian case study of best practices, Amfiteatru Economic Journal, 15(34), 518-531.

Gruian, C.M. (2010). What do we mean by "Company performance"?, Analele Universităţii "Constantin Brâncuşi”" din Târgu Jiu, Seria Economie, No. 4. Retrieved from: https://www.utgjiu.ro/revista/ec/pdf/2010-04.I/24_CLAUDIU_MARIAN_GRUIAN.pdf.

Hassab Elnaby, H.R., Hwang, W., Vonderembse, M. A. (2012). The impact of ERP implementation on organizational capabilities and firm performance, Benchmarking: An International Journal, 19(4/5), 618-633, DOI: DOI 10.1108/14635771211258043.

Hung, B.Q. (2009). The relationship of software fit and organizational resistance on the success of accounting software implementation in Hochiminh city, Vietnam, Accounting and Management Information Systems, 8(2), 263-285.

Hunton, J.E., Lippincott, B., Reck, J.L. (2003). Enterprise resource planning (ERP) systems: comparing firm performance of adopters and non-adopters, International Journal of Accounting Information Systems, vol. 4, 165-184.

Joblist.md (2016). Ce este ERP și cum te ajută să îţi dezvolţi afacerea?. Retrieved from: https://joblist.md/ro/news/angajatorului/ce-este-erp-shi-cum-te-ajuta-sa-itzi-dezvoltziafacerea.

Lečić, D., Kupusinac, A. (2013). The Impact of ERP Systems on Business Decision-Making, TEM Journal, 2(4), 323-326.

Madapusi, A., D'Souza, D. (2012). The influence of ERP system implementation on the operational performance of an organization, International Journal of Information Management, 32, 24-34, DOI: doi:10.1016/j.ijinfomgt.2011.06.004.

Muhindo, A., Mzuza, M. K., Zhou, J. (2014). Impact of Accounting Information Systems on Profitability of Small Scale Businesses: A Case of Kampala City in Uganda, International Journal of Academic Research in Management (IJARM), 3(2), 185-192.

Nicolaou, A.I., Bhattacharya, S. (2006). Organizational performance effects of ERP systems usage: The impact of post-implementation changes, International Journal of Accounting Information Systems, 7, 18-35, DOI: doi:10.1016/j.accinf.2005.12.002.

Oracle România (2020). Ce este ERP?. Retrieved from: https://www.oracle.com/ro/erp/what-iserp/. 
Poston, R.; Grabski, S. (2001). Financial impact of enterprise resource planning implementations, International Journal of Accounting Information Systems, 2(4), 271-294.

Stanciu, V., Tinca, A. (2013), ERP solutions between success and failure. Accounting and Management Information Systems, 12(4), 626-649.

Tobon, V. E., Lamouri, S., Pellerin, R., Dubois, P., Moeuf, A. (2018). The integration of ERP and inter-intra organizational information systems: A literature review, IFAC Papers Online, no. 51-11, 1212-1217.

Umble, E.J., Haft, R.R., Umble, M.M (2003). Enterprise resource planning: Implementation procedures and critical success factors, European Journal of Operational Research, no. 146, 241-257.

Velcu, O. (2007). Exploring the effects of ERP systems on organizational performance. Evidence from Finnish companies, Industrial Management \& Data Systems, 107(9), 1316-1334, DOI: 10.1108/02635570710833983.

Wieder, B., Booth, P., Matolcsy, Z. P., Ossimitz, M.L. (2007). The impact of ERP systems on firm and business process performance, Emerald Group Publishing. Retrieved from: http://epress.lib.uts.edu.au/research/handle/10453/4076. 